Journal of Economics and Behavioral Studies

Vol. 4, No. 4, pp. 204-210, Apr 2012 (ISSN: 2220-6140)

\title{
Cellular Services Packages and their Impact on Social Values of Youth
}

\author{
*Syed Saad Hussain Shah, Sidra Waris, Jabran Aziz, Ahsan Raza Jaffari, Maira Fatima, Wasiq Ejaz, Syed Kamran \\ Sherazi, Kashif Ur Rehman \\ Iqra University, Islamabad Campus, Pakistan \\ *saadihussain@live.com
}

\begin{abstract}
Youth plays a significant role in building of the nation and in the development of a country. Their adoption, aspiration, and objective lead towards change in social value of a culture. Ongoing study investigates the impact of telecom cellular services packages like late night call \& unlimited Short Messaging Service (SMS) on the social values of Pakistani youth. In today's competitive environment cellular companies are mainly targeting youth through their advertisements and would like the youth to get indulge in these activities in order to increase their sales but the point is up to what extent youth showing receptiveness and emotional attachment to these packages. Study was conducted in capital city of Pakistan i.e. Islamabad, mainly considering three famous universities; Iqra University, Bahria University \& Foundation University with the sample of 250 respondents; convenient sampling technique is used \& results are measured using multiple regression test. Major findings concluded that cellular advertisements of unlimited Short Messaging Service (SMS) and late night call packages have a negative impact on youth but youth is still willing to accept these advertisements as they are negatively attached to the advertisement and use of these packages.
\end{abstract}

Keywords: Advertisements, late night call packages, SMS, social values, cellular services, youth

\section{Introduction}

In the current telecommunication scenario of Pakistan, there are a number of mobile call packages existing in market. These include special discounts \& unlimited SMS \& late night call options have been introduced. Due to this reason the providers of cellular services are having a closer look for the migration of Personal computer consumers to become the cell phone user e.g. "GPRS rates have gone down, for example a user can send hundreds of text messages per day to any network in the country". Ijaz (2008) was of the view that late night call packages mostly targeted youth that influences mostly at the $11^{\text {th }}$ hour of night to early in the morning round about at 7.00am. Mostly all telecom services companies are doing so like Warid Telecom providing night package with the name infinite craze or zem nites similarly Mobilink telecom night package such as raat shuru baat shuru. Likewise, youth is mature and now parents do not take a closer look at their children because the parents look at the things in different view as compared to youth so as a result positive or negative things are also perceived in different ways. The packages that were previously discussed in any case surely have affects on the study, healthy life, and business life of youth due to staying up long at nights (Ijaz, 2008). Furthermore, the students (youth) will let their peers know about these services "word of mouth" is started we can say peer education begins and one can say immature group of humans acting as profession to teach different or additional immature group of humans (Clements and Buczkiewicz, 1993) and students are discussing their academic work even on SMS.

Cell phones nowadays considered by youth as "symbol of independence" (Bhatti, 2008) they develop their own social groups and are able to elaborate or make one's self owned body of words to communicate in the social gathering that is far from unnecessarily curious sight of their guardian. This service is now utilized by youth in larger numbers i.e. 24/7, continues, and more over has been made as an intimate relation allowed before the marriage traditionally. Conversations are mainly done in bedrooms e.g. SMS or late night call packages. Youth is making social ties away from their families and the interaction betwixt the guardians and their children's came into being as non-personal. If someone says that love is in the environment or surrounding seems like it's being in accordance of the surrounding because mobile carry texts related to romance and youth are focusing to the usage of these cellular services for the maintenance of their close and loveable relational ties. Cellular companies are "grabbing our new generation, these calling free night 
packages services provided by our Cellular Companies have become a great pleasure/encouragement to people like who aren't responsible at all", and looks like beyond morals because whole night indulging in these kind of activities affects own cultural and traditional values (Bhatti, 2008). In Pakistan services related to cellular has started in the 1990's where telephone licenses for mobile services were assigned to Pakistan Telecom and Pakistan Communication known as the Insta Phone for the clause as a legal instrument of providing telephony services through mobiles. As a result now five companies that are providing cellular services exists in Pakistan namely as Ufone, Zong, Warid, Telenor \& Mobilink. Balaji et al, (2005) perceived and found that currently companies related to mobiles now focusing for the building of having a broad way plan of action to satisfy the consumers for the ongoing services that dominates amusement, \& loss in royalties for services and retaining consumers.

"Ideas associated with 'risk society' have become part of the organizing ground, which serves to define and order the 'personal' and social spaces' integral to its 'youth problem" (Epstein, 1998). Risk of misusing these late night call packages and unlimited SMS usage is always there and another service known as friend finder service launched by cellular companies affecting social values of youth in great deal too. What follows is an exploration of this idea both for understanding agency in youth, and for further developing the aims and objectives of a critical sociology of youth (Furlong and Cartmel, 1997), psychological effect is there, and youth is emotionally attached to these services now. Morris and Venkatesh (2000) were of the view that "Age has been of significant interest to social psychologists as well as marketers in the past"; these cellular companies are mainly targeting youth for subscription of late night call packages and unlimited SMS. "SMS was built into the European Global System for Mobile (GSM) working as an additional capability (Goggin et al, 2005). Now in many countries SMS perceived as cheap, utilized as one-to-one, or one-to-many, mostly communication is done in leisure time. New culture of media use started by young people thorough SMS but In Hong Kong, for instance, SMS was not accepted too quickly because voice mobile call charges were relatively cheap. Many industries are now interested to use this technology as may telecom services industries are doing so, specially new entrants Zong Is focusing on this strategy. Capitalizing on this unexpected boom, mobile carriers are seeking to position MMS (multimedia services) as the successor to SMS, supported by heavy marketing to promote consumer adoption of new mobile phones with picture and video capacity."

Following are the research questions:

- Are the advertisements affecting the social values of youth?

- Is the youth well aware about the importance of advertisements in the scope of their social values?

\section{Literature Review}

Attracting consumers of different cultures and having different social values marked as a challenge for international advertisers. On the other hand, at a gradual pace, service businesses are contributing to grow in the enclosed area internationally (Kothani, 1988; Dahringer, 1991). These strategies for people (youth) of different cultures \& social values arguments shows that there is need to understood the marketing internationally that is marked as immediately noticeable and has strong impression. Similarly broad way plan of action for advertisement is also required for the services and on the other hand, as well as domestic advertising growth strategies should become compulsory for companies like cellular services. The research in remote period suggests that advertisement of mobiles that is focused towards the act of permitting worthy of being accepted as compared to the several different advertisements (Barwise and Strong, 2002). Research determines that our youth get attracted by mobile music services advertisements. Moreover, they use it for entertainment purpose. The word Qos can explain in terms of "the collective effect of service performances, which determine the degree of satisfaction of a user of the service." Wu (2000) was of the view that userperceived QoS becomes of vital importance due to the advancement in mobile technology therefore customers expectation increased in view of wireless technologies. Therefore, in these current scenario exertions of the strength developed for the explanation of Qos with additional detail considering consumer perspectives and linkage of a belief for the particular parameters of cellular structure in form of concept is being considered today (Saliba et al, 2005). Moreover, there are implications of studies that conclude that "effective network performances, wired and wireless," are of major importance in satisfying customer experiences as compared to characteristics of the network. If we emphasize on the importance of experienced consumers in context of notion of QoS (Saliba et al, 2005) cellular companies are focusing on improving their 
services to a level at which customers become satisfied for better communication like unlimited SMS \& late night call packages.

"Quality is defined as the overall excellence or superiority that consumers perceive from a product/service" (Zeithaml, 1988). Cronin et al, (2000) explained, "Consumer perceptions of service quality, value, and satisfaction have been extensively studied as antecedents of loyalty intention." On the other hand, satisfaction is defined as "a mediator between quality and/or value and customer retention" (McDougall and Levesque, 2000). In these context cellular services, companies are focusing to retain their customers by giving quality services with timely delivery of unlimited SMS package. Population should be literate who will understand the advertised messages, therefore there is a need of hour that population must be of right age \& right gender \& must have sufficient funds or sum of money to consume the products \& services that are offered in the market (Dyer, 1995).

\section{H1: Cellular advertisement has significant relationship with the social values of people.}

Brierly (1995) said that most people just take 1.5 seconds to read a printed advertisement so advertisement must be made precise \& brief. On the other hand the social groups identifies themselves based on same attitudes, shared consumption patterns (Goldman, 1992). Advertisers focus on the group they want to focus for instance woman is found to be in a homogenous groups and advertisements prepared in the house for household items. This variable mobile advertisement helps us to find out the impact of mobile advertisements on social values of youth. Advertisement of the mobiles seems as pleasing to the sight of the customer due to its less amount and strong infiltration (Barwise and Strong, 2002). The people related to advertisement made vigilant alerts, call, audio and video texts and messages communicative streaming of videos are made in order to grasp the attention of the consumers usually with the help of developing the messaging in personalized form. In today's world, cellular services are attracting more customers by introducing services like late night call packages and unlimited SMS, making attractive advertisements and commercials e.g. Mobilink Raat Shuru Baat Shuru slogans. The mobile entertainment industry acts as a foundation of m-commerce (Tsalgatidou and Pitoura 2001; Panis et al, 2002). One more thing left, which is acting as an indicator i.e. what attracts and influence our youth in deciding to adopt cellular service. Furthermore, which specific features they would like a mobile entertainment application to offer (Balasubramanian et al, 2002).

Researching on the study of Consumer behavior is vital towards increasing the pace in diffusion and consumer acceptance of using m-commerce services (Green et al 2001). It is proposed that the attached emotions with the cellular's or mobiles can be named as a key that has an impact on the newly born latest services for the admission in the future prospects (Vincent, 2006). Consumer receptiveness is critical in finding out whether people accept the advertisement or not. Swaminathan et al, (1996) was of the view that advertisements classified mainly as "(cognition or affect)" so in these scopes emotional advertisements means serving advertisements to focus "elicit affective responses" (Aaker and Stayman, 1992). However, most studies concluded that emotional responses, which are positive, results in positive advertisement and generally in brand responses. Advertisements which are get reacted through cognitive reactions are affected much positively through the help of advertising that is un emotional in nature that has power of attracting in contrast to advertisements that are emotional in nature (De Pelsmacker et al, 2002).

H2: Consumer receptiveness has significant relationship with the social values of people.

If we look cellular's through view of product extension they are currently extensions of own (Hulme, 2003; Lasen, 2004; Vincent, 2005) and considered as showing similarity in the condition of being deprived of extension (Hulme, 2003). Consumers currently view them as unavoidable so as a result attachment to these cellular devices has increased as users intended to arouse the emotions with these cells (Fox, 2001; Lasen 2004, 2005; Vincent, 2005; 2006). Cellular services are increasing rapidly as building upon premise that leaves its footprints on future acceptance of new services (Vincent, 2006). However, there exists a lacking rigid and accurate speculation in addition to that verifiable scientific investigation when viewing commercial functions involved in transferring goods from producers to consumers with act of implicating the act of using commerce through mobile or cell (Balasubramanian et.al, 2002). Consumer behavior of using commerce through mobile is not being marked as title of enough scientific investigation (Green et al 2001). There is a bulk of researches and discussions on the emerging business models of mobile entertainment industry which acts as a trusted market in m-commerce (Tsalgatidou and Pitoura 2001; Panis et al, 2002). Furthermore, we 
can still be able to find out indicators i.e. what influences consumers in their decision to accept and adopt cellular music services (Balasubramanian et.al, 2002). Moreover, emotional feeling of affection also determines the cellular device in managing the person confidential as well as life relating to emotions (Henley management college, 2003), we will try to scrutinize in view of customers willingness to accept the advertisement of cellular's or not.

If we view pure services from a nature perspective, they are intangible; means are not capable to be grasping or touched psychologically (Bateson, 1979). Therefore, the participation of a particular branch of learning, science, or art regarding morality principals with relative worth, rules of right conduct main beliefs with the help of honest principles inside commerce (Paine, 1996) are must for cellular companies to focus as a basic research area in business ethics. Low impact on moral values of the youth \& help youth to become emotionally socialize well as, Cutler and Javalgi (1993) founded that the service advertisers target ads emotionally, Similarly (Bulter and Abernethy, 1994) marked partial digits that belongs to knowledge communicated stimuli utilization belonging to services provider. Cellular companies must focus on providing the in depth detail of services offered that has an valid positive impact on youth, so the dependent variable social values will explain how youth get influenced by these services \& use these services in their social groups.

H3: Consumer attachments to advertisements have significant impact upon the social values of people.

\section{Framework of Study}

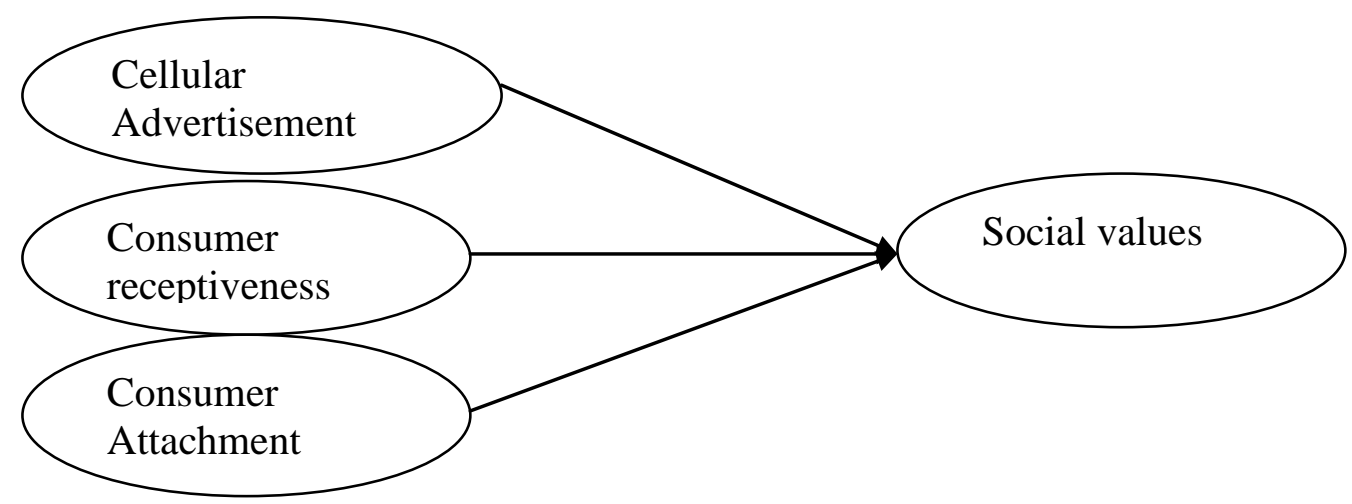

\section{Methodology}

Sampling: Non-random sampling technique is the one in which does not involve random selection. Sampling technique utilized in the research is non-probability random sampling because it is the most convenient way to gather the data; secondly, the research was not related to a particular group of employees so anybody could fill the questionnaire. Three universities namely as foundation, Bahria \& Iqra university were considered as the population of this study. Three hundred and eighty (380) questionnaires were distributed to the companies out of which 250 significant questionnaires were processed in the study, and thus a response rate of $81 \%$ was achieved.

Scales \& Measurements: Survey questionnaire consists of two parts; in the first part; personal profile of the students were inquired. The second section comprises of the questions related to the independent and the dependent variable. The items of the survey measured on five point Likert scale. SPSS software was used for the study. Questions were adapted from various research papers.

Procedure: The questionnaires were personally distributed among three universities situated in Islamabad. The questionnaires were almost self-explanatory. However, in case of any query the required assistance is offered. Data gathered from the employees was calculated with the help of SPSS software. The reliability of the measurements was checked by the means by using values of Cronbach's alpha generated through SPSS output. Reliability measures the continuity among different items of variable (Hair et.al, 1998). Multiple regressions consisting of Hierarchical regression were used to identify the relationship of the advertisement, 
receptiveness, and attachment on the social values of youth. The confidence interval for this study has been found to be ninety five (95) percent and significance level five (5) percent. To keep the validity and importance of the study, all the questionnaires were self administered and assisted, helping students in case of any queries. As a result, received datum systematically arranged; in addition to this with the absence of every all comparatively small numeric symbol, sheet of Statistical packages for the social sciences formed. Multiple linear regressions was utilized for hypothesis testing with the help of Statistical packages for the social sciences software version number 16.0 to find the relationship betwixt variables that are independent and dependent in nature.

\section{Results and Discussion}

\begin{tabular}{llllll}
\multicolumn{6}{l}{ Table: Co-efficient, Parenthesis (Standard Error), Brackets (t-value) and in italic (P-Value) } \\
\hline Constant & $\begin{array}{l}\text { Advertisement } \\
\text { (IV1) }\end{array}$ & $\begin{array}{l}\text { Receptiveness } \\
\text { (IV2) }\end{array}$ & $\begin{array}{l}\text { Attachment } \\
\text { (IV3) }\end{array}$ & R Square & F \\
\hline 4.542 & -.207 & .353 & -.232 & .725 & 128.580 \\
$.081)$ & $(.046)$ & $(.024)$ & $(.056)$ & & \\
{$[56.274]$} & {$[-4.512]$} & {$[14.776]$} & {$[-.4113]$} & & .000 \\
.000 & .000 & .000 & .000 & & \\
\hline
\end{tabular}

Results obtained show that as an individual co-efficient $\beta$ in case of each variable indicates a significant result overall. The investigation of this research shows that a social issue regarding youth indicates a powerful correlation with all the independent variables. Whole analysis shows that the variables advertisement, receptiveness and attachment which are independent in nature influences social values and gives a significant result as $\mathrm{P}<.05, \mathrm{~F}=128.580$ and the $\mathrm{R}$ Square $>.70$ whereas the standard error $<1$. For social values chosen variables advertisement and attachment which are independent in nature shows significant negative relationship, whereas the independent variable receptiveness show a significant positive value where $t$ also indicates positive result (Cooper and Schindler, 2003).

Discussion: The results above are significant with the past researches as relationship between the independent and dependent variables are in correspondence with the literature (see for example Barwise and Strong, 2002; Vincent, 2006; Swaminathan et al, 1996; Hulme, 2003; Lasen, 2004; Vincent, 2005; Cutler and Javalgi, 1993; Bulter and Abernethy, 1994).

\section{Conclusion}

The results thus obtained by the previously mentioned study leant that the hypothesis $\mathrm{H} 1$ is accepted for the independent variable advertisement that states; Cellular advertisement has negative impact upon the social values of Pakistani Youth. The second hypothesis $\mathrm{H} 2$ is also accepted for the independent variable receptiveness which states; Consumer receptiveness has positive impact upon the social values of Pakistani Youth. Similarly, hypothesis H3 is also accepted which states; Consumer attachment to late night call and unlimited SMS packages advertisement has negative impact upon the social values of Pakistani Youth. In sum, the advertisements and attachment to these advertisements are negatively co related to dependent variable social values, while consumer receptiveness is positively co related to dependent variable social values.

Contribution: The research will contribute to the literature, as the topic for research is a burning issue these days in the developing countries like Pakistan as economic downfall is there and youth is not taking things seriously and wasting their time by indulging themselves in these kinds of activities. These advertisements have a bad impact on the rich social value of our esteemed culture and we should not activate these packages as they are sources of wastage of time and money, health problems, and in short it disturbs the daily routine as night are to sleep not to wake all night long and do these stuff. As a concluding remark one could say that the majority of these packages ultimately destroys are social values, mostly the youth believes that these packages are bad but on the other hand they are willing to accept these packages as they are negatively associated with these.. It is recommended that future research should takes place in this regard by 
elaborating more key variables that are affecting the social values of youth and tries to identify steps to avoid wastage of the youth.

Limitations: Every study has its own limitations and no research is perfect, room for improvement is always there. In doing this research, researchers also face some problems. Basic issue of research is limitation of time which might results in lack of generalizability, target population is youth particularly from universities of Islamabad; many trends are different in different parts of the country. Result may vary from different social classes where as sample is from same social class. Specific segment of society is studied which cannot reveal the true position of society, that is why social values of that particular segment is studied. The same study can be extended to macro level for the generalizability of results. Youngsters who do not belong to universities may also be included for truer picture of the obtained results.

Recommendations: It is recommended by focusing on the results obtained and through the research that future researches must be put into the process of research by focusing on these advertisements, as now days it is a burning topic to research as these advertisements are influencing on youth where mainly students are using these packages on a larger scale. Some students also perceive these advertisements negatively. It is recommended cellular companies should focus on ethics where they are deliberating the image of organization; focus should not be on only earning money but to provide quality service at reducible cost rather than giving late night package for wastage of time. The cellular companies should play their role the giving the true image of social value and culture and the regulatory bodies should also closely monitor the activities of the cellular companies to safe guard the Pakistan's wealthy culture and highly regarded social values.

\section{References}

Aaker, D. A. \& Stayman, D. M. (1992). Implementing the concept of transformational advertising. Psychology and Marketing, 9(3), 237-253.

Balaji T. S., Landers, B., Kates, J. \& Moritz, B. (2005). A carrier's perspective on creating a mobile multimedia service. Communications of the ACM, 48(7), 49-53.

Balasubramanian, S., Peterson, A. R. \& Jarvenpaa, L. S. (2002). Exploring the Implications of M-commerce for Markets and Marketing. Journal of the Academy of Marketing Science, 30 (4), 348-361.

Barwise, P. \& Strong, C. (2002). Permission-based mobile advertising. Journal of Interactive Marketing, 16(1), $14-24$.

Bhatti, B. (2008). Competitive Trends, Education, Mobile Content, Mobile Phones, Mobile Trends, Privacy, Social Networks, Telecommunications'. (http://telecompk.net/2008/12/16/late-night-callingpackages-and-pakistani-youth-2/).

Brierly, S. (1995). The Advertising Hand book, London: Rout ledge.

Bulter, D. D. \& Abernethy, A. M. (1994). Information consumers seek from advertisements: are there differences between goods and services? Journal of Professional Services Marketing, 10(2), 75-92.

Bateson, J. E. G. (1979). Why we need service marketing, In Ferrell, O.C., Brown. S.W. and Lamb, C.W. (Eds), Conceptual and Theoretical Developments in Marketing, American Marketing Association, Chicago, IL.

Cutler, B. D. \& Javalgi, R. G. (1993). Analysis of print ad features: services versus products. Journal of Advertising Research, 33(2), 62-9.

Clements, I. \& Buczkiewicz, M. (1993). Approaches to Peer-led Health Education: A Guide for Youth Workers, Health Education Authority, London.

Cronin, J. J., Brady, M. K. \& Hult, G. T. (2000). Assessing the effects of quality, value, and customer satisfaction on consumer behavioral intentions in service environments. Journal of Retailing, 76(2), 193-219.

Cooper, D. R. \& Schindler, P. S. (2003). Business Research Methods. $8^{\text {th }}$ Edition. New York: McGraw-Hill Irwin.

Dahringer, L. D. (1991). Marketing services internationally: barriers and management Strategies. Journal of Services Marketing, 5(3), 5-17.

Dyer, G. (1995). Advertising as Communication, 6th Ed, and London: Rout ledge.

De Pelsmacker, P., Geuens, M. \& Anckaert, P. (2002). Media context and advertising effectiveness: the role of context appreciation and context-ad similarity. Journal of Advertising, 31(3), 25-37.

Epstein, J. (1998). Youth Culture: Identity in a Postmodern World, Blackwell. 
Fox, K. (2001). Evolution, alienation and gossip: The role of mobile telecommunications in the 21st century. Social Issues Research Centre. (http://www.sirc.org/publik/gossip.shtml).

Furlong, A. \& Cartmel, F. (1997). Young People and Social Change. Routledge.

Green, N., Harper, R. H. R., Murtagh, G. \& Cooper, G. (2001). Configuring the mobile user: Sociological and Industry views. Personal \& Ubiquitous Computing, 5(2), 146-156.

Goggin, S., Gerard, A. \& Christina, S. (2005). Mobile message services and communications policy. Prometheus, 23(2), 181-193.

Goldman, R. (1992). Reading Ads Socially, London: Rout ledge.

Henley Management College. (2003). People discover the joy of text. Summit (no. 8) (http://www.henleymc.ac.uk/henleymc03.nsf/files/SummitIssue8.pdf/\$FILE/SummitIssue8.pdf).

Hair, J. F., Anderson, R. E., Tatham, R. L. \& Black, W. C. (1998). Multivariate Data Analysis, Fifth edition, Prentice-Hall International, Inc.

Hulme, M. (2003). Me, my phone and I'. Michael Hulme. (http://www.michaelhulme.co.uk/papers.html).

Ijaz, O. (2008). Competitive Trends, Marketing, Mobile Companies, Mobile Trends, Mobilink, Pakistan, Telenor, Ufone, Warid, Zong'. (http://telecompk.net/2008/12/15/late-night-calling-packages-andpakistani-youth-1/).

Kothani, V. (1988). Strategic dimensions of global marketing of services. Journal of Professional Services Marketing, 3(3/4), 209-29.

Lasen, A. (2005). History repeating? A comparison of the launch, uses of fixed and mobile phones, In Mobile world: Past, present and future, ed. L. Hamill and A. Lasen, 29-60.

Lasen, A. (2004). Affective technologies - Emotions and mobile phones (http://www.vodafone.com/flash/receiver/11/articles/pdf/11_03.pdf).

McDougall, H. G. \& Levesque, T. (2000). Customer satisfaction with services: putting perceived value into the equation. Journal of Services Marketing, 14(5), 392-410.

Morris, M. G. \& Venkatesh, V. (2000). Age differences in technology adoption decisions: implications for a changing work force. Personnel Psychology, 53(2), 375-403.

Panis, P., Morphis, N., Felt, E., Reufenheuser, B., Bohm, A., Nitz, J. \& Saarlo, P. (2002). Mobile Commerce Service Scenarios and Related Business Models, Proceedings of the 1st International Conference on Mobile Business, Athens-Greece, 8-9 July.

Paine, L. S. (1996). Moral thinking in management. Business Ethics Quarterly, 6(4).

Swaminathan, V., Zinkhan, G. M. \& Reddy, S. K. (1996). The evolution and antecedents of Transformational advertising: a conceptual model. Advances in Consumer Research, 23, 49-55.

Saliba, A. J., Beresford, M. A., Ivanovich, M. \& Fitzpatrick, P. (2005). User-perceived quality of service in wireless data networks. Personal and Ubiquitous Computing, 9, 413-422.

Tsalgatidou, A. \& Pitoura, E. (2001). Business models and transactions in mobile electronic commerce: requirements and properties. Computer Networks, 37(2), 221-236.

Vincent, J. (2005). Emotional attachment to mobile phones, In Thumb culture, the meaning of mobile phones in society, ed. P. Glotz, S. Bertschi, and C. Locke, 95-104.

Vincent, J. (2006). Emotional attachment and mobile phones. In Thumb culture: the meaning of mobile phones for society, ed. S. Bertschi and P. Glotz, 117-22, Transcript Verlag/Transaction US.

Venkatesh, V., Morris, M. G. \& Ackerman, P. L. (2000). A longitudinal field investigation of gender differences in individual technology adoption decision-making processes. Organizational Behavior and Human Decision Processes, 83(1), 33-60.

Uma, S. (2000). Research Methods for Business: A Skill-Building Approach. Third Edition, John Wiley \& Sons, Inc. New York, USA.

$\mathrm{Wu}$, J. (2000). Performance analysis of QoS-based voice/data CDMA systems. Wireless Personal Communications, 13, 223-236.

Zeithaml, V. A. (1988). Consumer perceptions of price, quality, and value: a means-end model and synthesis of evidence. Journal of Marketing, 52(3), 31-46. 